\title{
POTENCIAL DE ESTRATÉGIAS DE RACIONALIZAÇÃO DO CONSUMO DE ÁGUA POTÁVEL APLICADAS A UM PROJETO DE EDIFÍCIO EDUCACIONAL NO SEMIÁRIDO BRASILEIRO
}

\author{
POTENCIAL DE ESTRATEGIAS DE RACIONALIZACIÓN PARA EL CONSUMO DE AGUA POTABLE \\ APLICADAS A UN PROYECTO EDUCATIVO EN EL SEMIARIDO BRASILEÑO
}

\section{POTENTIAL OF RATIONALIZATION STRATEGIES FOR DRINKING WATER CONSUMPTION APPLIED TO AN EDUCATIONAL BUILDING PROJECT IN THE BRAZILIAN SEMI-ARID CLIMATE}

\section{DANTAS, PETTERSON MICHEL}

Mestre em Arquitetura, Projeto e Meio Ambiente pela Universidade Federal do Rio Grande do Norte (UFRN), Professor do Instituto Federal de Educação, Ciência e Tecnologia do Rio Grande do Norte (IFRN). E-mail: petterson.dantas@ifrn.edu.br

\section{GOULART, SOLANGE VIRGINIA GALARCA}

Doutora pela Architectural Association School of Architecture (Londres), Professora do Departamento de Arquitetura e Urbanismo da Universidade Federal do Rio Grande do Norte (UFRN). E-mail: solange.goulart@ufrn.br.

\section{RESUMO}

A falta de água potável para consumo é um grave problema mundial. A escassez natural é um dos fatores que limitam a disponibilidade de água para populações, mas em alguns casos esta condição é acentuada pelo crescimento urbano sem infraestrutura prévia, que compromete a qualidade das reservas hídricas nas cidades. A conservação da água potável deve ser uma das principais preocupações dos projetos arquitetônicos para edificações mais sustentáveis. Inserido nesta discussão, este artigo apresenta um projeto de arquitetura para um edifício de uso educacional com foco na racionalização do consumo de água. 0 projeto foi proposto para a unidade da UFRN no município de Currais Novos, localizado em área de clima quente e seco. A proposta buscou integrar medidas de redução do consumo de água potável à arquitetura, com a finalidade de explorar qual a economia alcançada, utilizando-se de três princípios: utilização de equipamentos economizadores, aproveitamento de água da chuva e reuso de águas cinzas. Ao comparar dois cenários simulados - um considerando-se o prédio com as instalações hidráulicas convencionais e outro com a aplicação das medidas estudadas - os cálculos realizados indicaram que a edificação pode ter um consumo de áqua potável até $56 \%$ menor, se utilizadas as medidas estudadas. 0 artigo apresenta detalhadamente as etapas para cálculo e simulacão do consumo e traz uma breve discussão sobre a contribuição da arquitetura para as medidas de racionalização do consumo de água, a partir da especificação de dispositivos, definição de volumes e localização dos reservatórios e do desenho da cobertura, por exemplo.

PALAVRAS-CHAVE: projeto arquitetônico; racionalização do consumo de água; conservação da água, economia de água potável, aproveitamento de água da chuva.

\section{RESUMEN}

La falta de agua potable para el consumo es un grave problema mundial. La escasez natural es uno de los factores que limitan la disponibilidad de agua para las poblaciones, pero en algunos casos esta condición se ve acentuada por el crecimiento urbano sin infraestructura previa, que compromete la calidad de las reservas de agua en las ciudades. La conservación del agua potable debe ser una preocupación importante en los proyectos arquitectónicos para edificaciones más sostenibles. Insertado en esta discusión, este artículo presenta un proyecto arquitectónico para un edificio de uso educativo con un enfoque en la racionalización del consumo de agua. El proyecto fue destinado a la unidad UFRN en el municipio de Currais Novos, ubicada en una zona de clima cálido y seco. La propuesta buscó integrar medidas para reducir el consumo de agua potable en la arquitectura, con el propósito de explorar qué ahorros se lograron, utilizando tres principios: uso de equipos de ahorro, uso de agua de lluvia y reutilización de aguas grises. Al comparar dos escenarios simulados, uno considerando el edificio con las instalaciones hidráulicas convencionales y otro con la aplicación de las medidas estudiadas, los cálculos realizados indicaron que el edificio puede consumir hasta un $56 \%$ menos agua potable, si se utilizan las medidas estudiadas. El artículo presenta en detalle los pasos para calcular y simular consumos y también trae una breve discusión sobre la contribución de la arquitectura para las medidas para racionalizar el consumo de agua, a partir de la especificación de dispositivos, definición de volúmenes y ubicación de reservorios y el diseño de la cubierta, por ejemplo.

PALABRAS CLAVES: proyecto arquitectónico; racionalización del consumo de agua; conservación de agua, ahorro de agua potable, uso de agua de lluvia.

\section{ABSTRACT}

The lack of drinking water for consumption is a serious problem worldwide. Natural scarcity is one of the factors that limit the availability of water for populations, but in some cases this condition is accentuated by urban growth without prior infrastructure, which compromises the quality of water reserves in cities. The conservation of drinking water must be a major concern in architectural projects to more sustainable buildings. Inserted in this discussion, this article presents an architectural project for a building for educational use with a focus on rationalizing water consumption. The project was proposed for the UFRN unit in the city of Currais Novos, located in 
an area of hot and dry climate. The proposal sought to integrate measures to reduce drinking water consumption into architecture, with the purpose of exploring what savings were achieved, using three principles: use of saving equipment, use of rainwater and reuse of gray water. When comparing two simulated scenarios - first considering the building with the conventional hydraulic installations and second with the application of the studied measures - the calculations performed indicated that the building can consume up to $56 \%$ less drinking water, if the consumption rationalization measures are used. The paper presents in detail the steps for calculating and simulating consumption and also brings a brief discussion on the contribution of architecture to measures for rationalize water consumption, from the specification of devices, definition of volumes and location of reservoirs and the design of the roof, for example.

KEYWORDS: architectural project; rationalization of water consumption; water conservation, drinking water saving, rainwater harvesting.

Recebido em: 17/03/2021 Aceito em: 16/08/2021

\section{INTRODUÇÃO}

As discussões sobre sustentabilidade têm influenciado o comportamento das pessoas e o posicionamento de setores produtivos, como o da construção civil. Diversas iniciativas buscam aperfeiçoar o desempenho dos edifícios desde sua concepção à utilização, atuando principalmente sobre a conservação da água, eficiência energética, uso eficiente das matérias-primas e o manejo do canteiro de obras.

Neste contexto, a questão da conservação da água tem sua importância devido à escassez em certas regiões, assim como ao comprometimento da qualidade das reservas hídricas dos centros urbanos. Em regiões áridas, há muito tempo as populações desenvolveram hábitos de economia e formas de captar água enfrentando as condições impostas pelo meio, seja por meio de poços perfurados em leitos secos de rios, ou do armazenamento de água da chuva em cisternas. Com a contaminação das reservas em áreas urbanas, algumas das estratégias utilizadas em áreas de escassez passaram a ser vistas, juntamente com outras medidas, como alternativas para redução do consumo de água nas edificações.

Em algumas cidades do mundo, existem incentivos e exigências legais para redução do consumo de água potável, por meio da instalação de mecanismos para aproveitamento de água pluvial ou peças sanitárias economizadoras. De acordo com Tomaz (2005), na cidade norte-americana de Austin, no Texas, que apresenta uma média pluviométrica anual de $810 \mathrm{~mm}$, é fornecido auxílio financeiro ao cidadão que desejar instalar sistema de captação de água de chuva. Segundo Roaf, Fuentes e Thomas (2007), no Reino Unido, algumas companhias de água oferecem taxas reduzidas se o usuário puder comprovar que a água acumulada no telhado ou em outra superfície não está sendo descarregada na rede pública.

No Brasil, também surgiram legislações para evitar acúmulo de água na rede pública, causando enchentes, como a Lei estadual 12.526/2007, do Estado de São Paulo, que tornou obrigatória a implantação de sistema para captação e retenção de águas pluviais coletadas por telhados, coberturas, terraços e pavimentos descobertos, em lotes edificados ou não, que tenham área impermeabilizada superior a $500 \mathrm{~m}^{2}$.

Em novembro de 2019, o Sindicato da Indústria da Construção Civil do Estado de São Paulo (SindusConSP), a Câmara Brasileira da Indústria da Construção (CBIC) e o Comitê de Construção (CB2) da Associação Brasileira de Normas Técnicas (ABNT), atuando proativamente nesse contexto, trabalharam em três normas que abordam e incentivam práticas ligadas à gestão integrada de recursos hídricos: conservação de água em edificações (ABNT NBR 16.782:2019), uso de fontes alternativas não potáveis em edificações (ABNT NBR 16.783:2019) e aproveitamento de água de chuva para fins não potáveis (ABNT NBR 15.527:2019).

Para obter os mais altos níveis de desempenho ambiental nas edificações, entre outros aspectos, sempre é exigida a comprovação de um grande potencial de economia de água potável. Esta tem se tornado uma questão corrente nos projetos contemporâneos, que deve ser pensada desde a fase de concepção. Quando tais soluções dependem de projetos complementares desenvolvidos somente após o arquitetônico, podem trazer conflito ou mesmo impedir o máximo aproveitamento do sistema. Além da compatibilização necessária, ao tratar esta questão como uma das intenções do projeto arquitetônico, acredita-se que é possível chegar a resultados de maior qualidade.

Diante deste cenário, este artigo apresenta o desenvolvimento de um projeto arquitetônico para uma edificação de uso educacional que tem como uma de suas premissas a racionalização do consumo de água. Seu objetivo é verificar o potencial de economia de água potável obtido com a implantação das medidas de racionalização estudadas e, por meio do desenvolvimento do projeto arquitetônico, também discutir sobre a influência dessas medidas na arquitetura. O projeto, desenvolvido como produto do Mestrado Profissional em Arquitetura, Projeto e Meio Ambiente da UFRN, foi proposto para o campus da instituição no município de Currais Novos e destinado a abrigar atividades do curso de Turismo no âmbito da graduação e pós-graduação. Situada no sertão norte-rio-grandense e com uma das pluviometrias mais baixas do país, a cidade de Currais Novos está a 172 km de distância de Natal, capital do estado. 
Para desenvolvimento do projeto arquitetônico, além das etapas usualmente presentes - definição de programa arquitetônico, identificação de condicionantes, processo de concepção e detalhamento do projeto - desde o início do processo foi considerada a intenção de empregar medidas de racionalização do consumo de água potável. Para verificar o potencial de economia de água potável alcançado, após a definição do projeto arquitetônico, foram realizadas duas simulações de consumo: uma da edificação projetada empregando instalações hidráulicas convencionais e outra incorporando todas as medidas de racionalização de consumo previstas. Com a comparação desses cenários, foi possível calcular a diferença de consumo entre os dois e o potencial de economia de água potável atingido.

Espera-se que as informações apresentadas neste trabalho contribuam para a difusão de tecnologias de racionalização do consumo de água nas edificações e estimulem suas aplicações em outros projetos de arquitetura.

\section{ARQUITETURA TRADICIONAL E CONSUMO DE ÁGUA EM REGIÕES SEMIÁRIDAS}

As regiões semiáridas caracterizam-se pelo clima quente e seco, a baixa umidade e pouca vegetação. Devido ao rigor do clima, a arquitetura desenvolvida nessas regiões reflete uma tentativa de isolamento do exterior e em função da sua escassez, a água se torna um bem de valor inestimável. Juntamente com questões culturais e a disponibilidade de materiais, as características do clima influenciam diretamente nas soluções arquitetônicas que se constituíram nas regiões quentes e secas do planeta. Esta influência é visível principalmente nas construções mais primitivas com função de abrigo, denominadas de vernaculares.

Para exemplificar construções adaptadas ao clima quente e seco, Bittencourt e Cândido (2006) fazem referências às edificações tradicionais da cultura árabe. De acordo com os autores, as construções vernaculares desta cultura refletem o clima apresentando pequenas aberturas, paredes espessas pintadas com cores claras e pátios, às vezes combinados à presença de fontes de água ou vegetação. A organização dos espaços em torno de um pátio resulta em uma edificação voltada para dentro, o que possibilita a troca de ar interno em temperaturas inferiores ao exterior.

Também são exemplos de construções vernaculares em clima quente e seco os Pueblos, comuns na porção Sudoeste dos Estados Unidos, conforme cita Romero (2000). Segundo a autora, estes tipos de abrigos caracterizam-se pelas construções compactas e sobrepostas, com vários andares, acessadas por meio de escadas de madeira. Os conjuntos geralmente são organizados em torno de um espaço aberto e construídos com pedra, barro e madeira. Em suma, a autora aponta quatro características favoráveis às construções das regiões de clima quente e seco: a ocupação densa, o sombreamento, a forma compacta e o uso da água para umidificação.

Voltando o olhar para uma realidade mais próxima, percebe-se que as antigas construções rurais do semiárido brasileiro, embora pertençam a uma cultura distinta, também recorrem a soluções semelhantes às de outros lugares de clima quente e seco, como por exemplo: paredes externas espessas, pequenas aberturas expostas, pé-direito alto e portas e janelas voltadas para um terraço coberto que funciona como espaço de transição entre o exterior e o interior.

Assim como em outras regiões secas, no semiárido brasileiro, dominante na região Nordeste do país, a escassez hídrica se reflete no consumo de água da população. Segundo dados do Sistema Nacional de Informações sobre Saneamento (BRASIL, 2019, p. 78), a região Nordeste do Brasil apresenta a menor média de consumo de água diário per capita do país, com 115,4 litros. A média nacional é de 154,9 litros e as demais regiões também apresentam valores mais elevados: região Norte, 131,80 litros; Sudeste, 182,6 litros; Sul, 146,1 litros; Centro-Oeste, 144,9 litros.

A própria escassez é uma das responsáveis pelo registro do menor consumo de água, seja pela intermitência no abastecimento decorrente da indisponibilidade hídrica, seja por influenciar nos hábitos da população. Para enfrentar este cenário, algumas práticas se tornaram comuns nas cidades do Nordeste. Na escala das soluções coletivas, a construção de açudes e barragens tornou-se comum ao longo do Século XX. Segundo Assunção e Livingstone (1993, p. 427), a construção de açudes públicos no Nordeste começou em 1890 no estado do Ceará e continuou praticamente sem interrupção até a década de 1990. Em 1906, foi criada uma instituição responsável por essa política, a qual desde 1945 tem o nome de Departamento Nacional de Obras contra as Secas (DNOCS). No fim de 1990, o DNOCS já contabilizava a construção de 295 açudes.

Nas últimas décadas, outra solução utilizada para enfrentamento da seca nas cidades do Nordeste foi a execução de adutoras que levam água para regiões mais secas, tendo destaque a polêmica transposição do Rio São Francisco. 
O aproveitamento da água da chuva também foi uma prática incentivada pelo governo federal nos últimos anos com o Programa das Cisternas iniciado em 2003. Ferreira e Figueiredo (2017) destacam o programa como uma medida efetiva de convivência com o semiárido, que virou política pública após ser fomentada e coordenada pela sociedade civil por meio da ASA - Articulação no Semiárido Brasileiro.

Soluções pontuais e de pequena escala também são empregadas, sobretudo no meio rural, como captação de água do subsolo, principalmente em leitos de rios e açudes, utilizando bombas ou cata-ventos para bombeamento da água à superfície.

O enfrentamento à situação de escassez obriga naturalmente à utilização de diferentes fontes de água e esta situação deve receber planejamento de longo prazo e em diferentes escalas. Mesmo quando uma cidade em área de escassez começa a ter um abastecimento de água relativamente regular, sua população não deve abandonar seu comportamento economizador e as edificações devem ser projetadas de forma a proteger a população do rigor do clima e contribuir com o uso racional de água.

\section{ARQUITETURA E CONSUMO DE ÁGUA EM EDIFÍCIOS PARA ENSINO}

As instituições de ensino superior geralmente são compostas por edifícios de usos distintos: administrativos, educacionais, área esportiva e convívio, entre outros. Contudo, a maior parte da área construída dos campi dessas instituições corresponde às edificações para ensino constituídas por salas de aulas e laboratórios.

Essas edificações apresentam características espaciais consolidadas, inerentes a seu uso. Alguns aspectos comuns a essas edificações em campi universitários são: ocupação por uma grande população, concentrada nos dias úteis e dividida em turnos; horizontalidade; grandes áreas de circulação, geralmente lineares ou contornando pátios; sequência de compartimentos de área semelhante, como salas de aulas.

Em relação ao uso da água nesses prédios, influenciam diretamente no consumo: a quantidade de usuários, seus hábitos e as características dos dispositivos hidrossanitários utilizados. O conhecimento do consumo em um edifício auxilia a reconhecer perdas por vazamentos ou falhas no sistema. Além disso, por meio do estudo dos usos finais da água pode-se identificar os aparelhos responsáveis por maior consumo e onde haverá maior relevância para intervenção nos sistemas prediais visando economia de água potável.

Embora o estudo de usos finais da água seja um tema recorrente, o estabelecimento de parâmetros de consumo para dimensionamento e simulação em edificações para ensino superior é um trabalho a ser aprofundado. Os resultados de uma pesquisa nem sempre podem ser aplicados a outras localizações em virtude das diferenças entre os hábitos de consumo, aparelhos sanitários utilizados e disponibilidade hídrica da região. Na ausência de parâmetros específicos para os edifícios para ensino superior, costuma-se dimensionar reservatórios de água para essas edificações utilizando-se os valores existentes para escolas de ensino médio e fundamental ou edifícios públicos ou comerciais. O valor de consumo mais difundido para esse uso é o proposto por Creder (2006, p. 9), de 50 litros/pessoa.dia.

Nos últimos anos, dados com valores menores vêm sendo apresentados em pesquisas realizadas por diversas instituições. Em um trabalho realizado em escolas de ensino fundamental e médio, a Companhia de Saneamento Básico do Estado de São Paulo (SABESP), chegou a um valor de consumo per capita de 25 litros/aluno.dia (SABESP, 2011). Medições específicas em universidades foram realizadas no Campus Darcy Ribeiro da Universidade de Brasília, onde após um programa de racionalização de consumo de água, foi registrado o valor de 21 litros/pessoa.dia (UNB, 2009).

Nakagawa (2009) estudou o consumo em 41 unidades na Universidade Federal da Bahia (UFBA) e encontrou uma média de consumo per capita de 30 litros/pessoa.dia, sendo que para as unidades de ensino que não dispõem de aparelhos especiais, tais como destiladores, foi registrado um consumo per capita inferior a 20 litros/pessoa.dia. Nas unidades de ensino de Arquitetura, Filosofia, Matemática, Letras e Direito, Nakagawa (2009, p. 54-56) registrou um consumo per capita de 14 litros/pessoa.dia, 16 litros/pessoa.dia, 12 litros/pessoa.dia, 15 litros/pessoa.dia e 18 litros/pessoa.dia, respectivamente.

Além do levantamento de parâmetros de consumo para o tipo específico da edificação, é importante identificar para quais usos a água se destina. Kammers e Ghisi (2006) estudaram o consumo de dez edifícios institucionais em Florianópolis, Santa Catarina, com o objetivo de fornecer parâmetros de usos finais de água em edifícios públicos. Os autores desenvolveram a pesquisa a partir do levantamento de dados junto à concessionária de água, entrevistas com os usuários e quantificações de campo, estimando o consumo de água para cada dispositivo sanitário. Segundo o estudo, os maiores consumos de água nessas edificações são devidos aos vasos sanitários e mictórios, que juntos representam $72,1 \%$ do consumo total. De acordo com os autores, esses dados indicam a possibilidade de utilização de uma fonte alternativa de 
água nesses edifícios, pois os pontos de maior consumo de água não necessitam, obrigatoriamente, de água potável.

Marinoski e Ghisi (2008) estudaram o aproveitamento de água pluvial para usos não potáveis em uma instituição de ensino na cidade de Florianópolis. Os resultados do estudo indicaram um potencial de economia de água potável de $45,8 \%$ e um período de retorno do investimento de 4 anos e 10 meses para a instalação do sistema. Segundo os autores, esses dados comprovam a viabilidade de implantação do sistema de aproveitamento de água pluvial no local, pois além de apresentar um período de retorno de investimento relativamente curto, proporciona grande potencial de economia de água potável.

Diversas são as iniciativas que buscam alternativas para o consumo de água e a partir das referências estudadas, verifica-se que atualmente a conservação da água nas edificações envolve basicamente dois aspectos: a gestão da demanda e a gestão da oferta. De acordo com Sodré, Fukasawa e Oliveira (2019, p. 25), a gestão da demanda corresponde ao conjunto de ações que visam permitir o uso da água apenas na quantidade necessária para o desempenho das atividades consumidoras, enquanto a gestão da oferta corresponde às ações disponibilização de água produzida na própria edificação, proveniente de fontes alternativas. São exemplos de ações de gestão da demanda: a medição setorizada, a detecção e controle de perdas no sistema predial e o emprego de mecanismos economizadores, como registros reguladores de vazão, válvulas com acionamento por sensores, torneiras com fechamento automático, arejadores e bacias sanitárias com dois fluxos. São exemplos de ações de gestão da oferta: o aproveitamento de água da chuva, o reuso de efluentes tratados, a água condensada em sistemas de ar-condicionado.

\section{METODOLOGIA}

O trabalho apresentado neste artigo caracteriza-se, quanto aos seus procedimentos, como estudo de caso, uma vez que trata de soluções de projeto de arquitetura para uma realidade específica. Seu desenvolvimento se baseia principalmente em atividades de dois campos: procedimentos para desenvolvimento de um projeto arquitetônico e procedimentos para quantificação do consumo de água das edificações. Os resultados do trabalho também apresentam caráter duplo, sendo o projeto um objeto de cunho propositivo e os dados de economia de água um produto quantitativo. Para tanto, sua execução foi dividida nas seguintes etapas:

- Estudo de características da arquitetura e o uso da água em áreas semiáridas e para edificações de ensino, que teve como procedimentos a realização de pesquisa bibliográfica relativa à arquitetura vernacular em áreas de clima quente e seco; características e parâmetros de consumo de água em edifícios para fins educacionais; estratégias para redução do consumo de água nas edificações e formas de calcular suas aplicações.

- Levantamento dos condicionantes do projeto, como informações sobre o local de desenvolvimento e dados pluviométricos para o município (Empresa de Pesquisa Agropecuária do Rio Grande do Norte - EMPARN).

- Fundamentação do desenvolvimento do projeto e das estratégias de racionalização do consumo de água, que foi composta pelos procedimentos: estimativa da população do projeto, pré-dimensionamento dos espaços e definição de parâmetros de consumo de água para simulação de consumo.

- Concepção e desenvolvimento do projeto, interpretando-se as informações identificadas nas etapas anteriores sob a forma de uma solução arquitetônica.

- Avaliação dos benefícios proporcionados pela redução do consumo de água potável na edificação, na qual se verificou o potencial de economia alcançado. Para tanto, foram realizadas duas simulações de consumo: uma da edificação projetada empregando instalações hidráulicas convencionais e outra incorporando as medidas de racionalização de consumo previstas. Com a comparação desses cenários, calculou-se a diferença de consumo e o potencial de economia de água potável atingido. Para quantificar os benefícios do uso de aparelhos economizadores e reuso de efluentes, foram realizados cálculos estimativos. Para a simulação do aproveitamento de água da chuva, utilizou-se o software Netuno 3.0 (GHISI, CORDOVA e ROCHA, 2011). Foram fontes de dados para a simulação: as vazões e volumes de consumo das peças sanitárias, dados de utilização das instalações dos banheiros e a precipitação diária para a cidade de Currais Novos, obtidos junto à EMPARN.

\section{FUNDAMENTOS DO PROJETO}

\section{Local de implantação do projeto e aspectos ambientais}

O município de Currais Novos situa-se na região Seridó, a $172 \mathrm{~km}$ de Natal, a capital do Estado. A unidade da UFRN em Currais Novos localiza-se na região Norte da cidade (Figura 1). A área para a locação do projeto foi definida pela disponibilidade de terreno e a partir das prescrições do plano diretor do campus. 
Figura 1: Localização do campus na cidade de Currais Novos e localização do terreno do projeto dentro do campus.

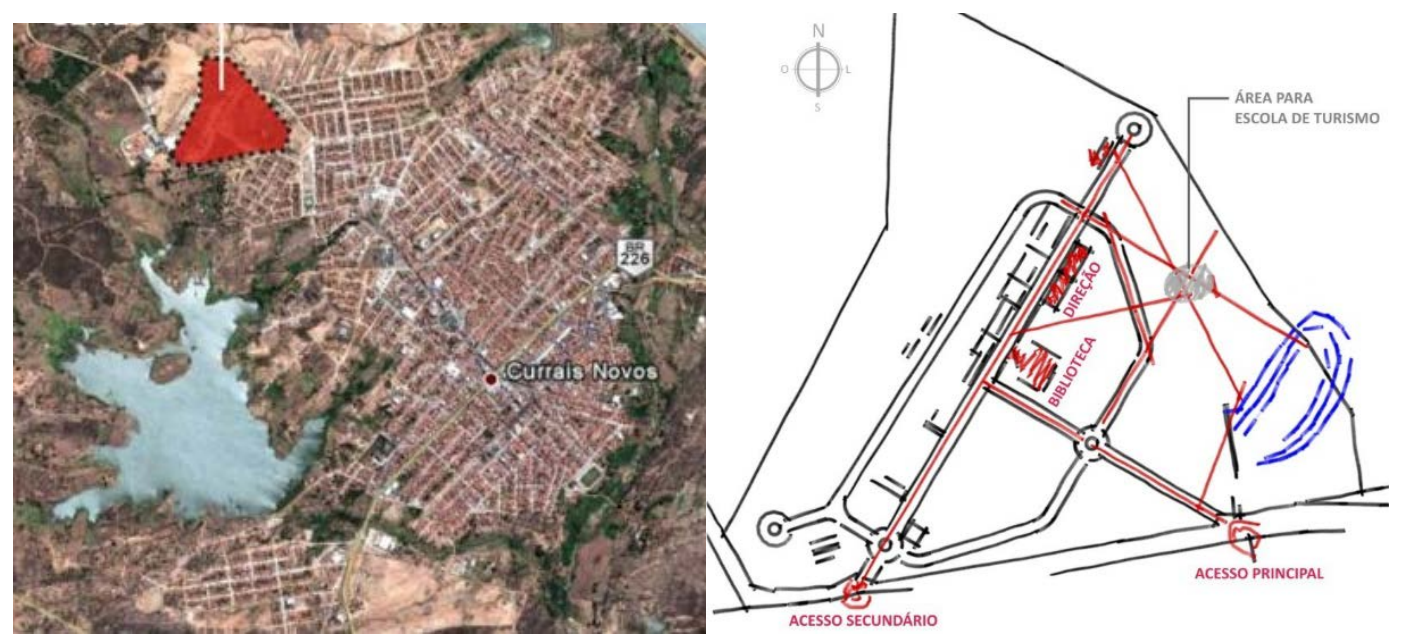

Fonte: Produção dos autores sobre base do Google Maps.

Com coordenadas $6,26 \mathrm{~S}$ e $36,52 \mathrm{~W}$, Currais Novos situa-se em uma região caracterizada pela vegetação de caatinga e clima quente e seco. O clima apresenta grande amplitude térmica, com as temperaturas mais baixas registradas em julho e agosto e as mais altas entre outubro e dezembro, com uma variação de amplitude diária média mensal em torno de $10^{\circ} \mathrm{C}$. As chuvas são concentradas no primeiro semestre, sobretudo em março e abril, quando ultrapassam os 100mm de precipitação (Figura 2).

Figura 2: Médias climatológicas de chuva e temperatura ao longo do ano para o município de Currais Novos-RN.

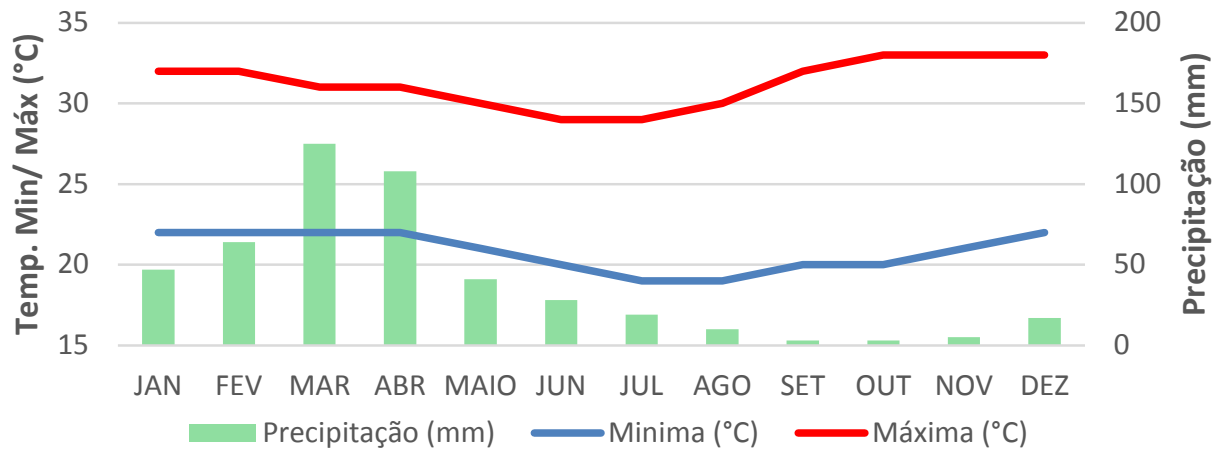

Fonte: Produção dos autores com dados de Climatempo (https://www.climatempo.com.br/climatologia/1371/curraisnovos-rn)

A área disponível para o projeto localiza-se na porção Leste do Campus. Nesta área, o terreno caracterizase por ser plano, de uma forma geral, havendo um aclive suave na direção Norte e um declive mais acentuado para o Sul, onde, mais adiante, a água se acumula formando um pequeno açude (Figura 1).

\section{Aspectos funcionais}

O projeto proposto é direcionado às demandas do curso de Turismo no âmbito da graduação e pósgraduação. A definição dos espaços que o compõem e a estimativa de sua população foram realizadas por meio de consultas a documentos, professores e estudos de referências de edifícios para fins educacionais.

O espaço físico voltado para o curso de Turismo visa fornecer ambientes para aulas práticas e teóricas e primeiros contatos com experiências profissionais. Além dos ambientes para aulas, são necessários espaços para suporte à atividade de ensino, como laboratórios para atividades de hotelaria, gastronomia, eventos e viagens. No âmbito deste projeto, os espaços previstos foram agrupados em cinco categorias, segundo suas funções: aulas, laboratórios, gabinetes, administração e espaços complementares. 
Para quantificar a população, verificou-se que o Bacharelado em Turismo consiste em um curso de tempo integral com duração de quatro anos. Na UFRN as turmas são compostas por até 50 alunos. O Mestrado em Turismo tem uma duração de dois anos, sendo as turmas formadas em geral por 20 alunos. A população estimada para o projeto está exposta no quadro abaixo e tendo em vista a predominância do público feminino no curso, foi considerado que $60 \%$ da população é formada por pessoas do gênero feminino e $40 \%$ do masculino. Além de ser utilizada para dimensionar espaços, a definição de quantidade de usuários também é necessária para estimar o consumo de água na edificação.

Quadro 1: Dimensionamento da população do projeto.

\begin{tabular}{llllll}
\hline USUÁRIOS & Alunos & Professores & Téc. Adm. & Manutenção & TOTAL \\
\hline QUANT. & 440 & 30 & 9 & 6 & $\begin{array}{l}\text { 485 pessoas } \\
\text { (291mulheres 194 homens) }\end{array}$ \\
\hline
\end{tabular}

Fonte: Autores.

\section{Dados para cálculo do consumo de água}

Para a posterior realização de simulações, foi necessário, primeiramente, estimar o consumo geral de água na edificação, a partir da bibliografia estudada. Para tanto, foi considerado o parâmetro de 25 litros/pessoa.dia (SABESP, 2011), por ser um valor intermediário entre as referências levantadas, o que resultou em um volume de consumo diário total de 12.125litros/dia.

Sabendo-se que para o tipo de uso desta edificação, as maiores oportunidades de economia de água potável encontram-se nas instalações dos banheiros, também foi realizado um levantamento de dados dos volumes de consumo e vazões dos aparelhos sanitários desses espaços. Para as variáveis de vazão de peças sanitárias foram considerados os valores constantes nas normas técnicas. Para o consumo de água de aparelhos com volumes fixos, tais como bacia sanitária com caixa acoplada, foram identificados juntos a fabricantes e apresentados a seguir:

Quadro 2: Parâmetros de consumo de água de peças sanitárias.

\begin{tabular}{lll}
\hline Peças sanitárias & $\begin{array}{l}\text { Volume do } \\
\text { aparelho (Va) }\end{array}$ & Vazão (V) \\
\hline Bacia sanitária comum com caixa acoplada (descarte de sólidos ou líquidos) & 6,0 litros & - \\
Bacia sanitária com duplo fluxo de descarga (descarte de líquidos) & 3,0 & - \\
Bacia sanitária com duplo fluxo de descarga (descarte de sólidos) & 6,0 & - \\
Lavatório com torneira convencional & - & 0,15 litros/s \\
Lavatório com torneira economizadora (arejador e fechamento automático) & - & 0,10 litros/s \\
Mictório convencional & 2,0 litros & - \\
Mictório economizador & 0,7 litros & \\
\hline
\end{tabular}

Fonte: Autores.

Para os dados de utilização das peças sanitárias (frequência e tempo de uso), visto que a edificação existe apenas no plano do projeto, não há como obter dados diretamente com a população do edifício. Em função disso, foram considerados os parâmetros levantados por Dantas (2012), em estudo piloto realizado na Escola de Ciência e Tecnologia, localizada no Campus Central da UFRN (Quadro 3).

Quadro 3: Parâmetros de consumo de água de peças sanitárias

\begin{tabular}{ll}
\hline Peças sanitárias & Parâmetro de utilização \\
\hline Bacia sanitária - descarga de 3 litros (mulheres) & 2 vezes/ dia \\
Bacia sanitária - descarga de 6 litros (todos) & 0,5 vezes/ dia \\
Lavatório com torneiras comum ou economizadora & 2 vezes/ dia \\
Lavatório com torneira economizadora & 2 vezes/ utilização \\
Mictório (homens) & 1,5 vezes/ dia \\
\hline
\end{tabular}

Estes dados, referentes a população, valores de consumo de água das peças sanitárias e hábitos de utilização embasaram os cálculos e a caracterização dos dois cenários estudados apresentados adiante. 


\section{CONCEPÇÃO DO PROJETO}

\section{Arquitetura}

A partir do estudo das condições do terreno, do clima quente e seco, das necessidades espaciais de um edifício para fins educacionais e dos princípios de economia de água, foi desenvolvida a proposta arquitetônica para Escola de Turismo, de autoria de Petterson Dantas.

Como estratégia bioclimática para o clima tropical quente e seco, foi projetada uma edificação voltada para dentro, com acesso convidativo e interior com a presença da água. Foi organizada volumetricamente a partir de três alas, em forma de "C", onde se encontram os espaços destinados a aulas, laboratórios, biblioteca, gabinetes e administração (Figura 3). Como um volume curvo independente, foi desenhado um auditório, ao lado de uma das extremidades do bloco em "C". Foram previstas circulações em todo o perímetro da edificação, que também contribuem para sombreamento das superfícies internas.

Figura 3: Croquis de concepção do projeto.
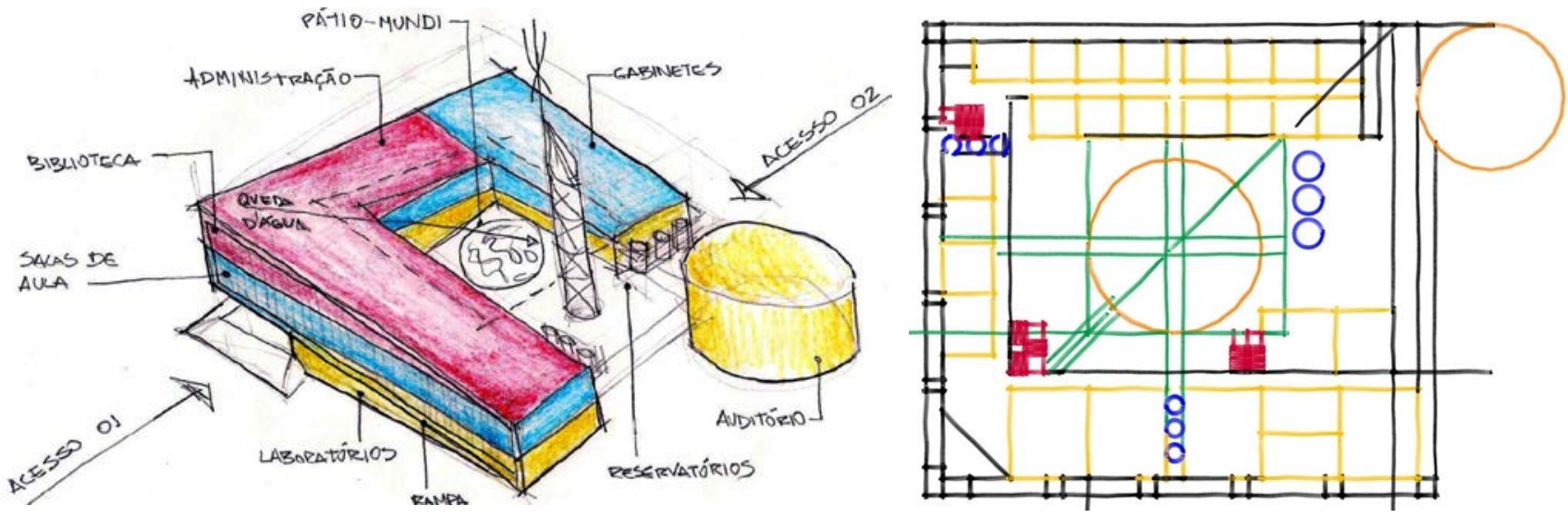

Fonte: Autores.

As circulações perimetrais foram convertidas em rampas em alguns trechos, viabilizando percursos acessíveis. A essas linhas inclinadas visíveis nas fachadas, juntou-se o desenho da cobertura, que apresenta seu ponto mais alto sobre o acesso principal da edificação e mais baixo nas proximidades do auditório.

Em função do topo inclinado, delimitado pela cobertura, a edificação foi organizada em pavimentos de áreas decrescentes. A porção central do Bloco em C apresenta três pavimentos, enquanto a extremidade ao Sul, dois e a extremidade ao Norte, próxima ao auditório, apenas um pavimento. Ainda como estratégia bioclimática, as fachadas receberam tratamentos diferentes em função das suas orientações: nas fachadas Leste e Oeste foram dispostas superfícies totalmente opacas e nas fachadas Norte e Sul foram propostos painéis de brises com uma diagramação colorida emoldurada pelas marquises, rampas e paredes laterais.

O sentido da inclinação da cobertura, definidora na concepção arquitetônica, surgiu da intenção de concentrar o fluxo de água da chuva em uma única área, onde foram previstos os reservatórios, o que também aproximou os condutores verticais de água. Para levar a água desses condutores aos reservatórios inferiores, foi projetado um pequeno espelho d'água, que ao mesmo tempo em que faz parte do sistema de aproveitamento de chuva, serve como estratégia de resfriamento evaporativo, indicada em áreas de clima seco.

O elemento de maior expressão das intenções do projeto foi a torre d'água, que agrupa os diferentes reservatórios de água da edificação, de acordo com seus usos: no compartimento mais alto, o reservatório de água potável, na porção central, os reservatórios de água pluvial e na parte mais baixa, o reservatório com água de reuso para irrigação. Unificado à estrutura da torre, foi planejada a instalação de um catavento para bombear a água, técnica muito difundida no semiárido nordestino (Figura 4). 
Figura 4: Imagens do projeto concluído: vista do acesso principal, fachada Sul e detalhe da torre d'água.
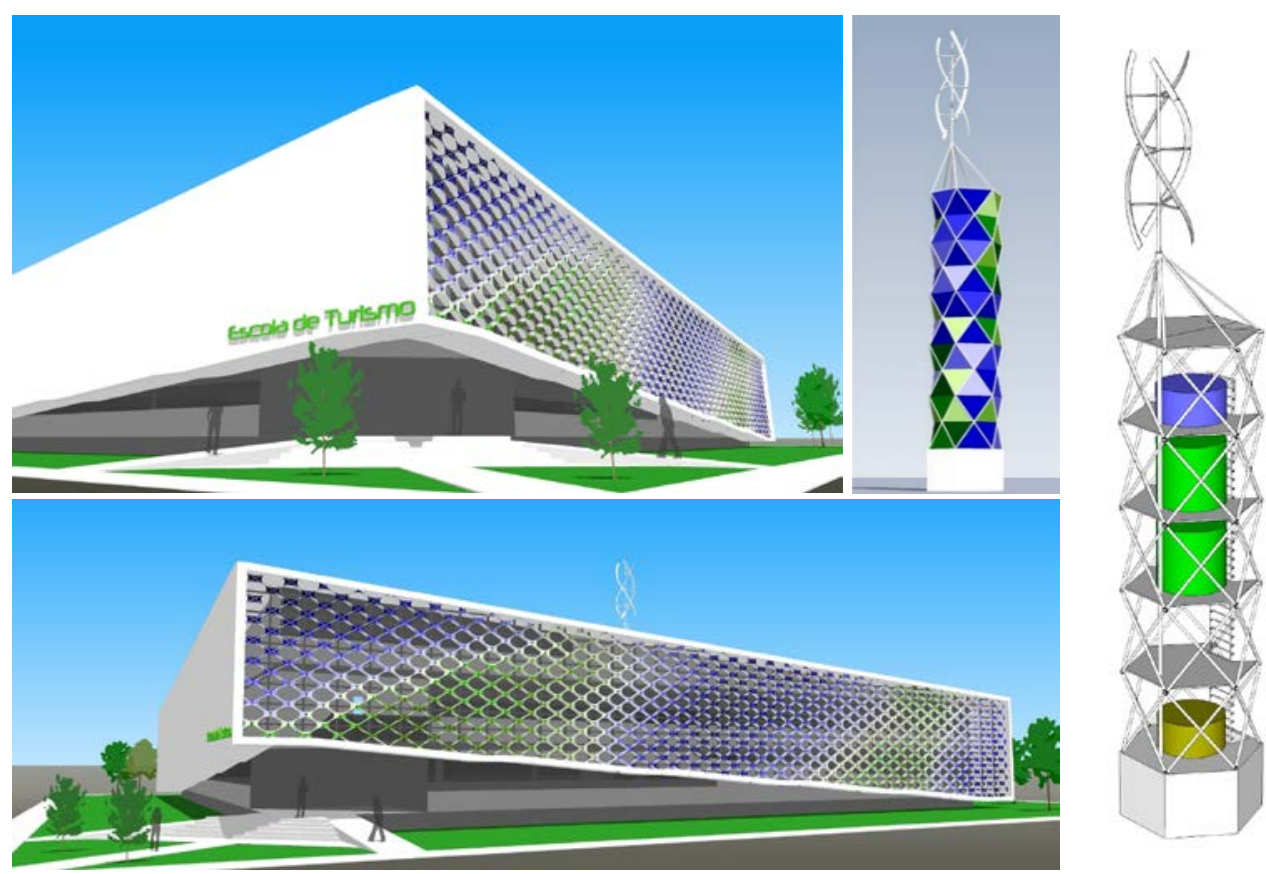

Fonte: Autores.

\section{AVALIAÇÃO DAS ESTRÉGIAS DE REDUÇÃO DO CONSUMO DE ÁGUA POTÁVEL}

Neste item são apresentados os dois cenários de estudo do projeto e a comparação do consumo de água nas duas situações, para cada estratégia adotada: emprego de mecanismos economizadores, utilização de água da chuva para descarga de sanitários e mictórios e o reuso de águas cinzas para irrigação.

\section{Caracterização das instalações hidráulicas do projeto e apresentação dos dois cenários estudados}

A figura 5-a ilustra o esquema das instalações hidráulicas do projeto no primeiro cenário estudado, com sistema convencional de abastecimento de água e tratamento de efluentes. No sistema convencional, o reservatório inferior é abastecido pela concessionária e por bombeamento, a água é levada para o reservatório superior. A partir daí, os pontos de consumo são abastecidos por gravidade. As instalações se baseiam em uma rede de abastecimento e outra de coleta. Todos os pontos de consumo recebem água potável, mesmo que seus usos não requeiram potabilidade e todos os efluentes têm a mesma destinação.

No segundo cenário de estudo a edificação passa a contar com mecanismos economizadores nos banheiros, captação de água de chuva na sua cobertura e aproveitamento para descarga em mictórios e sanitários e o reuso de efluentes para irrigação.

Para a implantação de instalações providas por fontes alternativas de água, o sistema passa a ter três redes de abastecimento de água: uma proveniente da concessionária, para usos potáveis, uma resultante da captação de água da chuva, para usos não potáveis e outra proveniente dos efluentes tratados do próprio edifício, utilizada para irrigação (Figura 5-b). Essas medidas atuam na entrada e saída do sistema, pois há redução do consumo de água potável, pelo suprimento por outras fontes e redução da produção de esgotos, com o reuso dos efluentes na irrigação. 
Figura 5: Esquema das instalações hidráulicas do projeto no primeiro cenário de estudo (a) e segundo cenário de estudo (b).

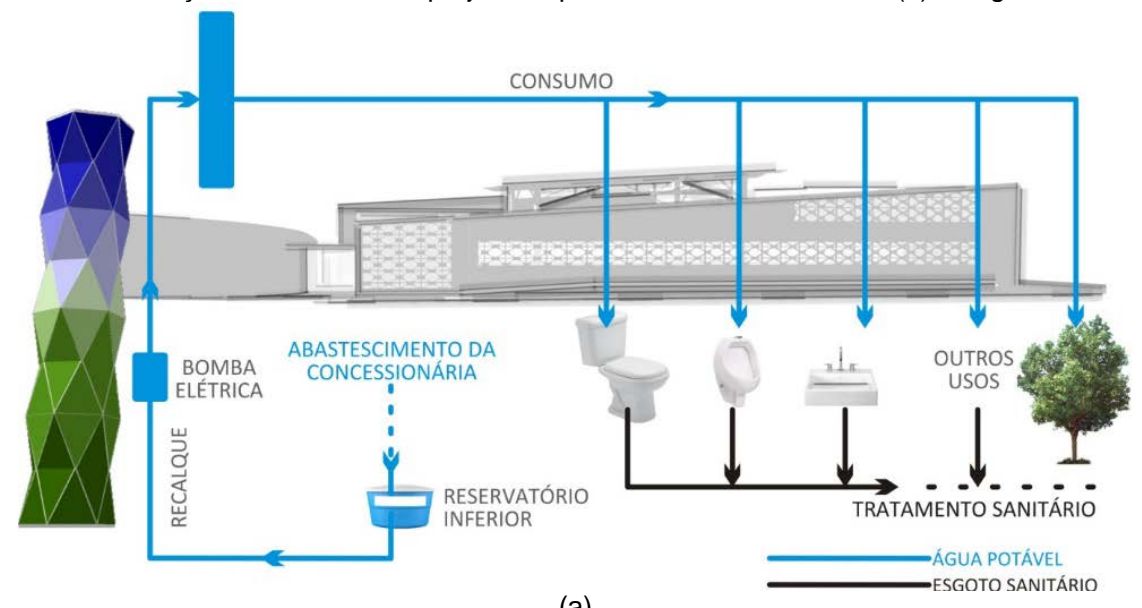

(a)

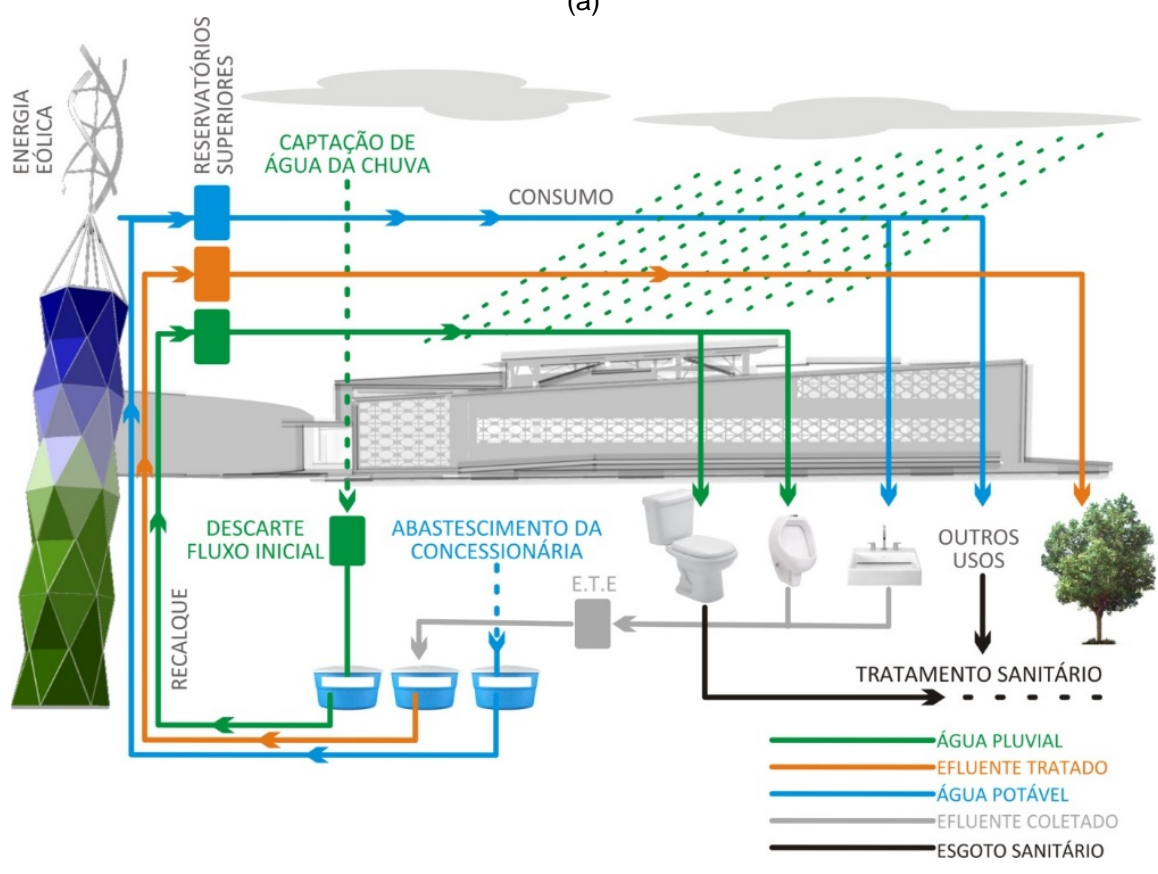

(b)

Fonte: Autores.

\section{Utilização de mecanismos economizadores nos banheiros}

Para reduzir o consumo de água foram empregados três tipos de mecanismos economizadores nos banheiros: torneiras com arejador e fechamento automático, válvula economizadora para mictórios e bacias sanitárias com duplo fluxo de descarga. Para realização do cálculo, foram considerados os valores de consumo, vazões e parâmetros de utilização apresentados anteriormente (Quadros 2 e 3). O cálculo do consumo nos banheiros da edificação com o uso de dispositivos convencionais é apresentado no Quadro 4.

Quadro 4: Simulação de consumo de água nos banheiros com uso de peças sanitárias convencionais.

\begin{tabular}{|c|c|c|c|c|c|c|c|}
\hline $\begin{array}{l}\text { Peças } \\
\text { sanitárias }\end{array}$ & Va (litros) & $\begin{array}{l}\mathrm{N} \\
\text { (vezes/dia) }\end{array}$ & $\begin{array}{l}\text { V } \\
\text { (litros/s) }\end{array}$ & $\begin{array}{l}\mathrm{Na} \\
\text { (vezes/uso) }\end{array}$ & $\begin{array}{l}\mathrm{T} \\
\text { (segundos) }\end{array}$ & $\begin{array}{l}\text { U } \\
\text { (usuários) }\end{array}$ & $\begin{array}{l}\text { Consumo } \\
\text { (litros/dia) }\end{array}$ \\
\hline Mictórios & 2,0 & 1,5 & - & - & - & 194 & 582,00 \\
\hline $\begin{array}{l}\text { Bacias sanit. } \\
\text { (líquidos) }\end{array}$ & 6,0 & 2 & - & - & - & 291 & 3492,00 \\
\hline $\begin{array}{l}\text { Bacias sanit. } \\
\text { (sólidos) }\end{array}$ & 6,0 & 0,5 & - & - & - & 485 & 1455,00 \\
\hline Lavatórios & - & 2 & 0,15 & 1 & 25 & 485 & 3637,50 \\
\hline TOTAL & & & & & & & 9166,50 \\
\hline
\end{tabular}

Fonte: Autores. 
Levando-se em conta a estimativa realizada anteriormente (no item Dados para cálculo do consumo de água), que resultou em um consumo total de 12.125,00 litros/dia de água na edificação e o valor de consumo para os banheiros de 9.166,50 litros/dia (Quadro 4), verifica-se que o consumo da água nos banheiros com dispositivos convencionais representa cerca de $75 \%$ do total da edificação.

Em seguida foi realizado novamente o cálculo para consumo estimado para os usos dos banheiros no cenário com emprego de dispositivos economizadores (Quadro 5).

Quadro 5: Simulação de consumo de água nos banheiros com uso de dispositivos economizadores.

\begin{tabular}{|c|c|c|c|c|c|c|c|}
\hline $\begin{array}{l}\text { Peças } \\
\text { sanitárias }\end{array}$ & $\begin{array}{l}\text { Va } \\
\text { (litros) }\end{array}$ & $\begin{array}{l}\mathbf{N} \\
\text { (vezes/dia) }\end{array}$ & $\begin{array}{l}\text { V } \\
\text { (litros/s) }\end{array}$ & $\begin{array}{l}\mathrm{Na} \\
\text { (vezes/uso) }\end{array}$ & $\begin{array}{l}\text { T } \\
\text { (segundos) }\end{array}$ & $\begin{array}{l}\text { U } \\
\text { (usuários) }\end{array}$ & $\begin{array}{l}\text { Consumo } \\
\text { (litros/dia) }\end{array}$ \\
\hline Mictórios & 0,7 & 1,5 & - & - & - & 194 & 203,70 \\
\hline $\begin{array}{l}\text { Bacias sanit. } \\
\text { (líquidos) }\end{array}$ & 3,0 & 2 & - & - & - & 291 & $1.746,00$ \\
\hline $\begin{array}{l}\text { Bacias sanit. } \\
\text { (sólidos) }\end{array}$ & 6,0 & 0,5 & - & - & - & 485 & $1.455,00$ \\
\hline Lavatórios & - & 2 & 0,1 & 2 & 6 & 485 & $1.164,00$ \\
\hline TOTAL & & & & & & & $4.568,70$ \\
\hline
\end{tabular}

Fonte: Autores.

A partir do cálculo realizado, verificou-se que a utilização de aparelhos economizadores reduz o consumo total nos banheiros de $9.166,50$ litros/dia para 4568,70 litros/dia.

Comparando-se o consumo para aparelhos convencionais e economizadores e individualizando-se os valores de cada peça sanitária, percebe-se que os pontos mais sensíveis à intervenção são os lavatórios e as bacias sanitárias. A economia de água alcançada com a substituição das válvulas dos mictórios foi pequena em valores absolutos, (378,30 litros/dia), porém considerável em termos relativos. O consumo em mictórios com válvulas economizadoras equivale a 35\% do consumo dos mictórios convencionais.

A economia total de água com o emprego de dispositivos economizadores representa uma redução de 50\%, considerando-se apenas o consumo nos banheiros. Em relação à demanda total de água estimada para 0 projeto, tais aparelhos contribuem para uma redução de 38\% do consumo (Figura 6).

Figura 6: Consumo diário de água no prédio considerando-se dispositivos convencionais e economizadores.

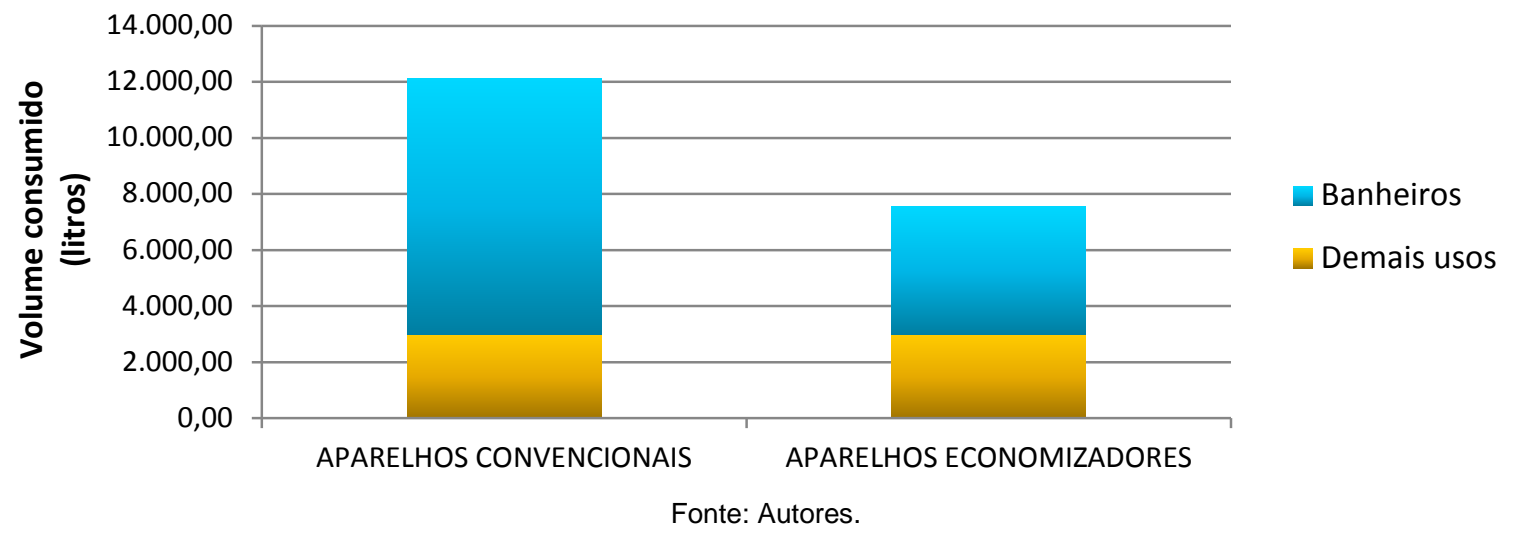

\section{Aproveitamento de água da chuva}

A segunda estratégia para economia de água potável empregada no projeto foi o aproveitamento de água da chuva para usos como descarga em bacias sanitárias e mictórios. Para o dimensionamento do reservatório para usos não potáveis, identificou-se primeiramente a demanda de água para as bacias sanitárias e mictórios, já considerando o uso de mecanismos economizadores (Quadro 5). Em seguida, foi realizada uma simulação do aproveitamento de água da chuva (Quadro 6) com o software Netuno (GHISI, CORDOVA e ROCHA, 2011) a partir dos dados de pluviometria diária para a cidade de Currais Novos durante os anos de 2008 e 2009 - únicos anos com dados registrados para todos os dias - obtidos junto à EMPARN. 
Quadro 6: Dados utilizados para simulação de aproveitamento de água da chuva no Software Netuno.

\begin{tabular}{|c|c|c|}
\hline Campo & Dados utilizados & Observação \\
\hline Pluviometria & $\begin{array}{l}\text { Currais Novos 2008-2009 } \\
\text { (EMPARN, 2010) }\end{array}$ & Ao todo, 731 dias. \\
\hline Área de captação & $2765,06 \mathrm{~m}^{2}$ & Calculada a partir do projeto. \\
\hline $\begin{array}{l}\text { Demanda de água per } \\
\text { capita }\end{array}$ & 7,02 litros/pessoa.dia & $\begin{array}{l}\text { Demanda per capita calculada para os usos nos quais se } \\
\text { utilizará água da chuva. }\end{array}$ \\
\hline Demanda fixa ou variável & Variável & \\
\hline Período de repetição & $\begin{array}{l}7 \text { dias }(5 \text { com demanda }= \\
7,02 \text { litros/pessoa e } 2 \text { com } \\
\text { demanda }=0)\end{array}$ & $\begin{array}{l}\text { Considerou-se que a Escola não funciona aos sábados e } \\
\text { domingos. Não se considerou o período de férias, por não se } \\
\text { ter dados de consumo para esse período. Algumas atividades } \\
\text { continuam na universidade mesmo nas férias. }\end{array}$ \\
\hline $\begin{array}{l}\text { Porcentagem de água } \\
\text { potável a ser substituída } \\
\text { por pluvial }\end{array}$ & $100 \%$ & $\begin{array}{l}\text { Considerou-se o aproveitamento de água de chuva para } \\
100 \% \text { da parcela que está sendo simulada }\end{array}$ \\
\hline $\begin{array}{l}\text { Coeficiente de } \\
\text { aproveitamento }\end{array}$ & 0,90 & $\begin{array}{l}\text { Calculado a partir da média pluviométrica dos dias chuvosos } \\
\text { acima de } 2 \mathrm{~mm} \text { em relação à média com descarte de } 2 \mathrm{~mm}\end{array}$ \\
\hline
\end{tabular}

A simulação (Figura 7) foi realizada com uma pequena diferença da forma usual de inserir os dados no programa. Normalmente são inseridos valores do consumo per capita de água potável total na edificação e o percentual para o qual se deseja utilizar água da chuva. Neste trabalho, optou-se por indicar o consumo per capita apenas dos usos para os quais se utilizará água da chuva e para o dado de percentual solicitado pelo programa inseriu-se 100\% (Quadro 6). Em função disso, o potencial de economia encontrado refere-se apenas ao volume que foi simulado - demanda para os mictórios e bacias sanitárias - e não para o consumo total do edifício. Acredita-se que a simulação nesse formato pode trazer melhores resultados, pois os dados inseridos não são estimativas em função do consumo total de água, mas sim valores calculados especificamente em função de cada peça sanitária e da população do edifício.

Figura 7: Simulação de aproveitamento de água da chuva para o projeto.

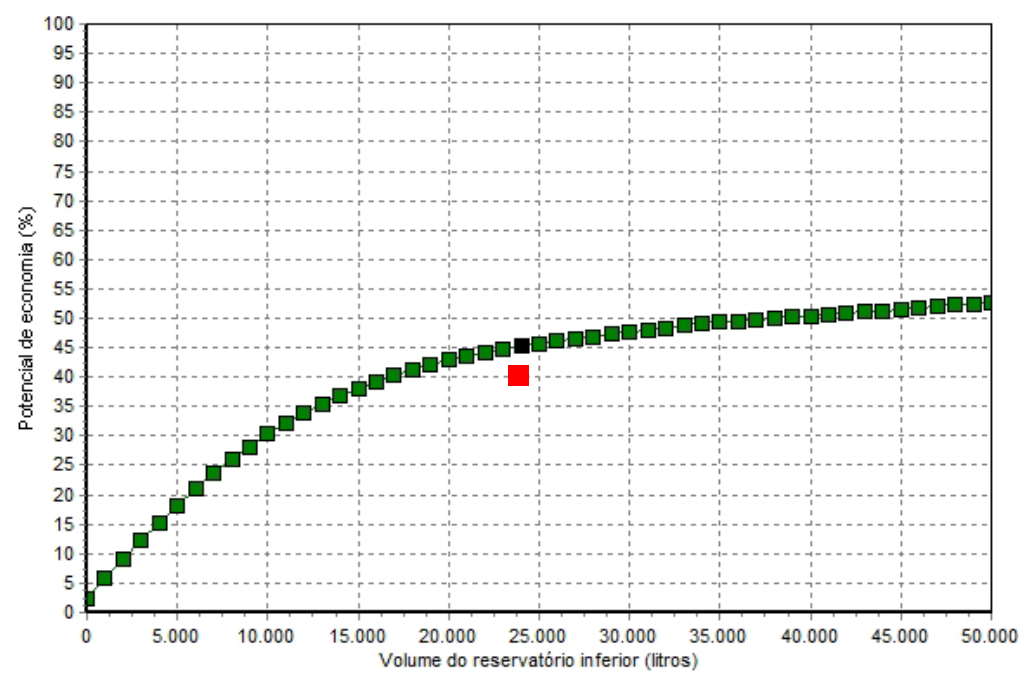

Fonte: Autores.

A simulação foi realizada para reservatórios de volumes diferentes, com intervalo de 1000 litros. Solicitou-se que o programa indicasse o volume ideal a ser utilizado, tendo como critério a diferença de $1 \%$ entre o percentual de economia dos reservatórios simulados. O resultado da simulação (Figura 7), indica um reservatório de 24.000 litros e um percentual de economia de água potável de 45,31\%.

O potencial de economia inferior a $100 \%$ indica que não é possível atender completamente a demanda identificada para os usos não potáveis. Um provável motivo para essa situação é a distribuição irregular das chuvas, concentradas em alguns meses, enquanto a demanda de água permanece por todo o ano. Em função disso, dos 3.404,70 litros de água diários destinados a usos não potáveis, 54,69\% continuam a ser providos por água da concessionária, enquanto $45,31 \%$ podem receber água pluvial, o que representa uma economia média de 1.542,67 litros/dia ao longo de um ano. 
Considerando-se o consumo de água total diário estimado do projeto já com o uso dos aparelhos economizadores, verificou-se que o aproveitamento de água de chuva representa uma redução média de $20 \%$ no consumo de água potável (Figura 8 ).

Figura 8: Comparação de consumo médio diário entre instalações convencionais e instalações com aproveitamento de água pluvial.

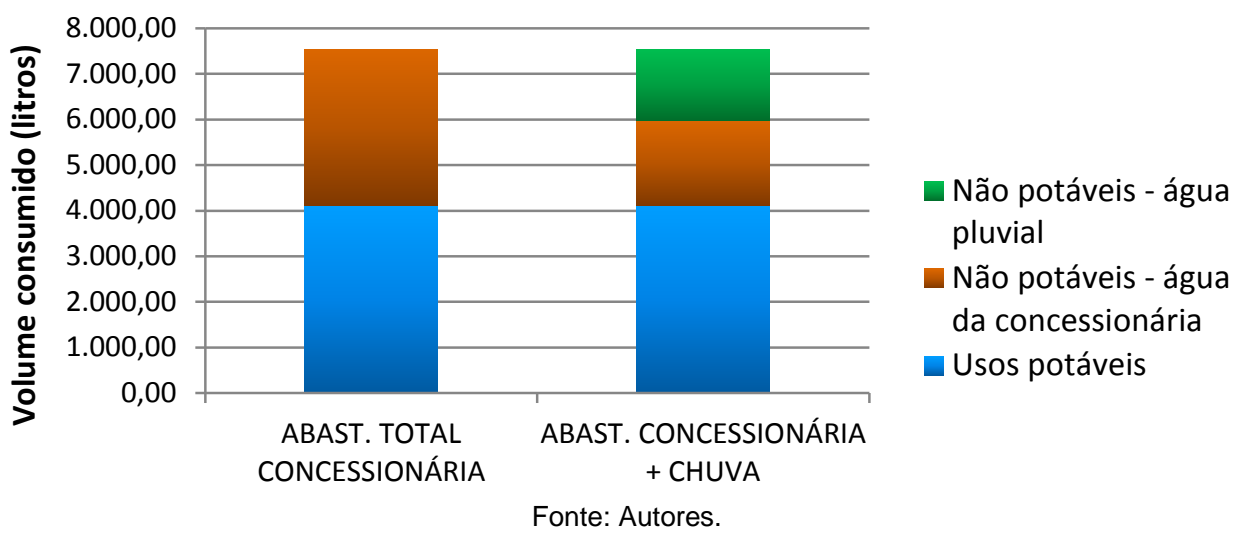

\section{Reuso de efluentes para irrigação}

No projeto proposto, optou-se por reutilizar apenas os efluentes dos lavatórios e mictórios, por apresentarem uma concentração de matéria orgânica inferior aos das bacias sanitárias. Como a disponibilidade de água para irrigação no projeto está diretamente relacionada à produção de efluentes, primeiramente foi identificado o volume gerado pelo consumo de água a partir dos dados do Quadro 5. Segundo o cálculo realizado, o uso dos lavatórios e mictórios gera 1.367,70 litros/dia de efluentes. Levandose em conta o parâmetro de 1,5 litros $/ \mathrm{m}^{2}$ para irrigação (CREDER, 2006, p. 9), identificou-se que é possível irrigar diariamente $911,80 \mathrm{~m}^{2}$ de jardim. Esta área corresponde à área permeável em torno do pátio, os canteiros nas duas entradas e mais uma faixa de $3 \mathrm{~m}$ de largura ao longo de três das fachadas do prédio (Figura 9).

Figura 9: Área passível de irrigação com efluentes tratados (a) planta de banheiro com identificação de destinos do esgoto gerado (b)

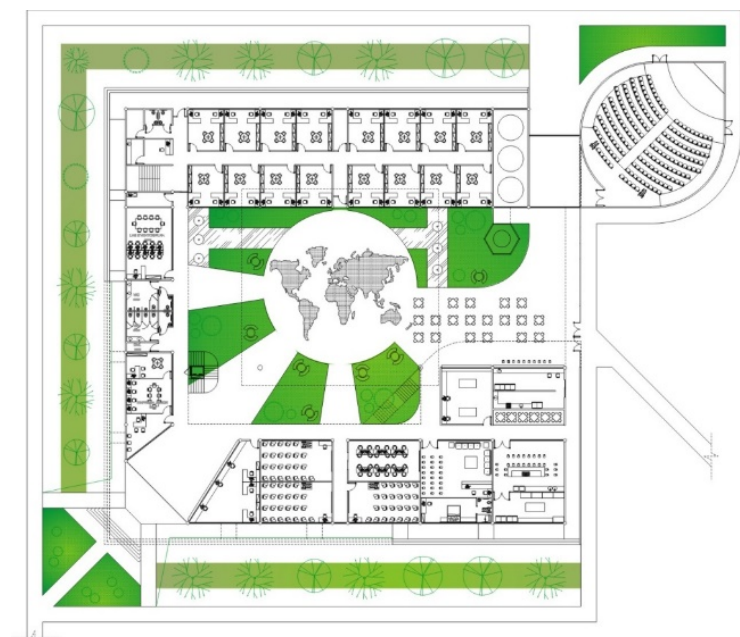

(a)

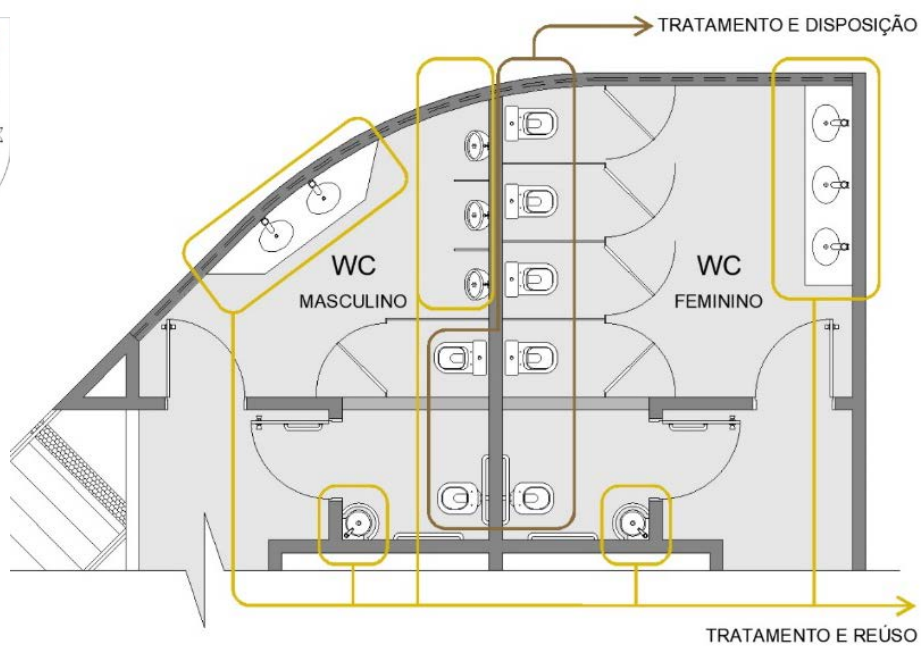

(b)

Fonte: Autores

\section{Síntese da economia alcançada}

A avaliação de um projeto de arquitetura pode abranger vários aspectos, tais como condições de conforto ambiental e aspectos construtivos. Ao longo do desenvolvimento deste projeto, tais questões estiveram presentes no processo, contudo, como se propôs inicialmente, o trabalho focou em uma contribuição pouco recorrente no âmbito de um projeto de arquitetura: a racionalização do consumo de água.

Para se quantificar os benefícios das soluções adotadas foram realizados cálculos e simulações e os resultados encontrados indicaram que é possível diminuir significativamente o consumo de água potável nos edifícios para ensino em universidades utilizando-se três princípios: redução do consumo de água no 
ponto de utilização, substituição da fonte de água e reciclagem interna. Sobrepondo-se o efeito de todas as estratégias adotadas e calculando-se o consumo de água diário na edificação, obteve-se a síntese da economia alcançada (Figura 10).

Figura 10: Síntese da economia de água potável estimada para o projeto (consumo médio diário).

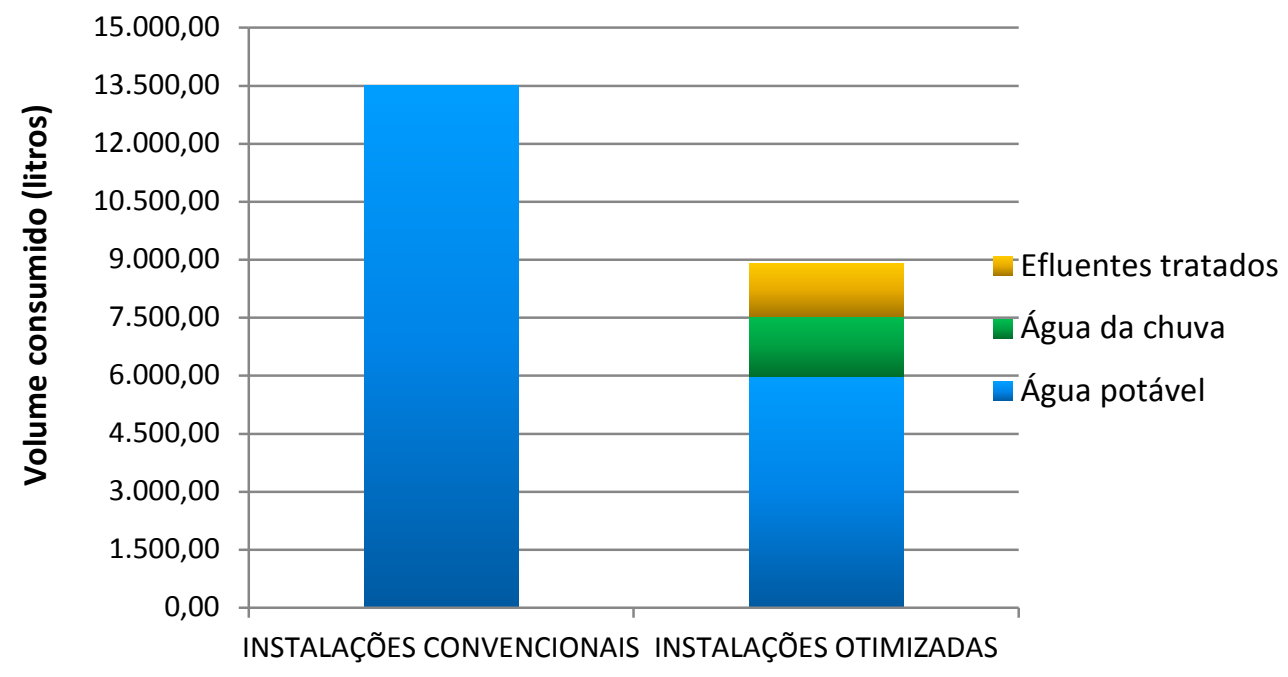

CENÁRIO 01

CENÁRIO 02

Fonte: Autores.

Comparando-se os dois cenários analisados, percebe-se que o consumo de 13.492,70litros/dia para o projeto com instalações convencionais (12.125,00 litros/dia para consumo na edificação e 1.367,70litros/dia para irrigação) pode ser reduzido para 8.894,90litros/dia com o uso das instalações racionalizadas.

Deste volume, apenas 5.984,53litros/dia são providos por água potável, o que corresponde a um consumo $56 \%$ menor. Em valores absolutos, as medidas utilizadas podem poupar, em média, 7.508,17litros/dia, sendo a estratégia de redução no ponto de utilização a que rendeu a maior economia (4.597,80litros/dia). A substituição de água potável pela água da chuva para descargas em bacias sanitárias e mictórios resultou em uma economia média de 1.542,67litros/dia de água e o reuso de efluentes também proporcionou um valor representativo, suficiente para dar autonomia à irrigação dos jardins do projeto, o que não aconteceria sem uma fonte alternativa, dado o cenário de escassez hídrica.

Para atingir esses resultados, são empregadas tecnologias disponíveis no mercado brasileiro, cuja instalação e manutenção não requer cuidados muito diferentes do que já é necessário para as instalações hidráulicas convencionais. Contudo, deve-se mencionar que existem custos adicionais para uma obra com instalações como as apresentadas neste projeto, devido à constituição de diferentes redes de água na edificação e aumento da capacidade de armazenamento de água, por exemplo.

O objetivo delimitado neste trabalho não envolve uma avaliação econômica do projeto, mas acredita-se que os custos adicionais decorrentes das soluções adotadas não sobrecarregam o orçamento da obra. Em uma consulta à Superintendência de Infraestrutura da UFRN, Dantas (2012, p. 106) identificou que o custo das instalações hidráulicas correspondia, em média, a 2,6\% do valor total das obras da universidade. Assim sendo, por mais que se duplique o custo das instalações hidráulicas em uma edificação como a apresentada neste trabalho, o valor continua a corresponder a uma pequena parcela do custo da obra, o que pode ser compensado após alguns anos pela economia de água potável.

\section{CONSIDERAÇÕES FINAIS}

Com esta experiência projetual, percebeu-se que a consideração de medidas de racionalização do consumo de água durante a concepção arquitetônica pode ser explorada de maneiras diferentes pelo projetista, resultando, ou não, em soluções visíveis aos usuários. Contudo, percebeu-se, também, que os melhores resultados para os sistemas são alcançados se a racionalização do consumo for premissa do projeto arquitetônico. 
Uma situação comum em projetos de arquitetura de uso institucional que pode ilustrar o peso das decisões arquitetônicas no consumo de água, por exemplo, é a decisão de o projetista inserir, ou não, mictórios nos banheiros coletivos masculinos. Sob o ponto de vista de resolução da planta, é muito mais fácil projetar os banheiros masculinos e femininos exatamente iguais, dentro de um bloco de serviços. Contudo, ao não dispor mictórios para o público masculino, o projetista está condicionando seus usuários a utilizarem as bacias sanitárias para descarte de resíduos líquidos, que apresentam um consumo de água de 3 a 7 vezes maior que o mictório.

Com relação às estratégias para redução do consumo de água potável adotadas neste trabalho, percebeuse que a mais integrada ao projeto de arquitetura é o aproveitamento de água de chuva, pois compartilha importantes elementos do projeto arquitetônico, como a cobertura. No projeto desenvolvido, por exemplo, o desenho da cobertura como área de captação foi definidor de pavimentos, fachadas e localização de reservatórios. A própria cobertura também fez papel de condutor horizontal, encaminhando a água precipitada na direção aos reservatórios inferiores.

Uma pergunta recorrente quando se apresenta um projeto arquitetônico com um sistema de aproveitamento de água de chuva é se seria possível desenvolver o projeto e somente depois da arquitetura definida decidir se inclui o aproveitamento de água da chuva.

A resposta seria que na maioria das vezes é possível, mas provavelmente com menor potencial de aproveitamento de água pluvial e com a inclusão de alguns elementos como calhas e tubulações verticais muitas vezes em conflito com a arquitetura, estrutura e demais instalações.

A interseção entre o projeto arquitetônico e as medidas de racionalização do consumo de água constitui um campo cada vez mais explorado nos projetos contemporâneos e a partir da experiência descrita neste trabalho, foram identificados alguns pontos nos quais a arquitetura pode contribuir com essas soluções:

- Especificação de dispositivos hidráulicos economizadores;

- Concepção de banheiros coletivos com mictórios para o público masculino;

- Integração dos diferentes reservatórios de água ao edifício;

- Localização dos reservatórios em função da fonte de água e dos pontos a serem alimentados;

- Integração de calhas e condutores de água à arquitetura do prédio;

- Desenvolvimento da cobertura da edificação com características favoráveis à captação de água da chuva: superfície lisa, com inclinação direcionada para onde se locou o reservatório inferior de água;

- Facilidade de manutenção dos sistemas de reuso de água e de aproveitamento de água da chuva, com acessos para todos os componentes.

Tais ações, combinadas às medidas de redução do consumo, proporcionaram o máximo aproveitamento dos recursos e instalações no projeto desenvolvido, o que resultou em uma economia de $56 \%$ no consumo de água potável, quando comparado ao cenário de instalações convencionais. Esse dado não deve ser entendido como um resultado pontual, pois traz benefícios em outros campos, que em uma primeira observação podem não ser percebidos. Traduzindo a informação sob a forma de indicadores ambientais, econômicos e sociais, este ganho representa, entre outros benefícios:

- Conservação de cerca de $1.801,96 \mathrm{~m}^{3}$ de água potável por ano;

- Redução de descarga de $875,25 \mathrm{~m}^{3}$ por ano de água pluvial nas vias ou coletores da universidade, em média;

- Redução da produção de $2.130,20 \mathrm{~m}^{3}$ de efluentes por ano;

- Difusão das tecnologias sustentáveis aplicadas às construções;

- Influência positiva no comportamento dos usuários da edificação quanto ao uso da água se o usuário tiver conhecimento das medidas utilizadas no projeto.

Nesta perspectiva, o projeto apresentado neste artigo pode ser entendido como uma exploração do potencial das tecnologias mais acessíveis para redução do consumo de água potável e um exemplo de edificação em sintonia com a questão da conservação da água potável, sobretudo em uma região de escassez hídrica. Espera-se que os resultados alcançados sirvam de referência para trabalhos posteriores e que estimulem a discussão sobre a integração da arquitetura e os demais projetos necessários para melhor desempenho ambiental das edificações. 


\section{REFERÊNCIAS}

ASSOCIAÇÃO BRASILEIRA DE NORMAS TÉCNICAS. NBR 15527: Aproveitamento de água de chuva de coberturas para fins não potáveis - Requisitos. Rio de Janeiro: ABNT, 2019. 10 p.

ASSOCIAÇÃO BRASILEIRA DE NORMAS TÉCNICAS. NBR 16782: Conservação de água em edificações - Requisitos, procedimentos e diretrizes. Rio de Janeiro: ABNT, 2019. $22 \mathrm{p}$.

ASSOCIAÇÃO BRASILEIRA DE NORMAS TÉCNICAS. NBR 16783: Uso de fontes alternativas de água não potável em edificações. Rio de Janeiro: ABNT, 2019. 19 p.

ASSUNÇÃO, Luiz Márcio; LIVINGSTONE, Ian. Desenvolvimento inadequado: construção de açudes e secas no sertão do Nordeste. Revista Brasileira de Economia, Rio de Janeiro, v. 47, n. 3, p.425-448, set. 1993. Disponível em: <http://bibliotecadigital.fgv.br/ojs/index.php/rbe/article/view/582>. Acesso em: 01 dez. 2020.

Brasil. Ministério do Desenvolvimento Regional. Secretaria Nacional de Saneamento - SNS. Sistema Nacional de Informações sobre Saneamento: 24 Diagnóstico dos Serviços de Água e Esgotos - 2018. Brasília: SNS/MDR, 2019. 180 p.: il.

BITTENCOURT, Leonardo; CÂNDIDO, Christina. Introdução à ventilação natural. Maceió: Edufal, 2006.

CREDER, Hélio. Instalações hidráulicas e sanitárias. 6. ed. Rio de Janeiro: LTC, 2006.

DANTAS, Petterson Michel. Projeto de um edifício para fins educacionais com foco na racionalização do consumo de água. 2012. 134 f. Dissertação (Mestrado) - Mestrado Profissional em Arquitetura, Projeto e Meio Ambiente, Universidade Federal do Rio Grande do Norte, Natal, 2012.

FERREIRA, José Gomes; FIGUEIREDO, Fábio Fonseca. Seca, memória e políticas públicas na região nordeste do Brasil. 2017. Disponível em: https://repositorio.ul.pt/bitstream/10451/33262/1/4294_jose_gomes_ferreira.pdf. Acesso em: 01 dez. 2020.

GHISI, E.; CORDOVA, M.M.; ROCHA, V. L. Netuno 3.0. Programa computacional. Universidade Federal de Santa Catarina, Departamento de Engenharia Civil. Disponível em: http://www.labeee.ufsc.br/. 2011.

KAMMERS, Pauline Cristiane; GHISI, Enedir. Usos finais de água em edifícios públicos localizados em Florianópolis, SC. Ambiente Construído, Porto Alegre, v. 6, n. 1, p.75-90, jan. 2006.

MARINOSKI, Ana Kelly; GHISI, Enedir. Aproveitamento de água pluvial para usos não potáveis em instituição de ensino: estudo de caso em Florianópolis - SC. Ambiente Construído, Porto Alegre, v. 8, n. 2, p.67-84, abr. 2008.

NAKAGAWA, Alessandra Leiko. Caracterização do consumo de água em prédios universitários: O caso da UFBA. 2009. 183 f. Dissertação (Mestrado) - UFBA, Salvador, 2009.

ROAF, Sue; FUENTES, Manuel; THOMAS, Stephanie. Ecohouse. 3. ed. Oxford: Elsevier, 2007.

ROMERO, Marta Adriana Bustos. Princípios bioclimáticos para o desenho urbano. Brasília: Copymarket.com, 2000.

SABESP. Companhia de Saneamento Básico do Estado de São Paulo. Uso racional da água: Ações. Disponível em: $<$ <ww.sabesp.com.br>. Acesso em: 25 abr. 2011.

SÃO PAULO. Lei no 12.526, de 02 de janeiro de 2007. Estabelece normas para a contenção de enchentes e destinação de águas pluviais. São Paulo, 02 jan. 2007.

SODRÉ, Virgínia Dias de Azevedo; FUKASAWA, Bruno Nogueira; OLIVEIRA, Marina Roque. Guia orientativo das normas de conservação de água, fontes alternativas não potáveis e aproveitamento de água de chuva em edificações. Brasília: Câmara Brasileira da Indústria da Construção - CBIC, 2019.

TOMAZ, Plíno. Aproveitamento de água de chuva para áreas urbanas e fins não potáveis. 2. ed. São Paulo: Navegar, 2005.

UNB AGÊNCIA. Consumo da água na UnB caiu 73\% nos últimos 16 anos: Melhorias na rede de fornecimento possibilitaram queda. Gasto por usuário está abaixo da média. Disponível em: <http://www.unb.br/noticias/unbagencia/unbagencia.php?id=1774>. Acesso em: 05 out. 2011.

NOTA DO EDITOR (*): O conteúdo do artigo e as imagens nele publicadas são de responsabilidade do(s) autor(es). 